\title{
A study of cytological pattern of cervical papanicolaou smears in western Rajasthan, India
}

\author{
Kiran Rawat ${ }^{1}$, Narendra Rawat ${ }^{2}$, Navgeet Mathur ${ }^{2} *$, Medha Mathur ${ }^{3}$, Nitesh Chauhan ${ }^{2}$, \\ Rajat Tinna ${ }^{2}$, Rahul Kakkar ${ }^{2}$
}

${ }^{1}$ Department of Pathology, ${ }^{2}$ Department of General Medicine, S. N. Medical College, Jodhpur, Rajasthan, India
${ }^{3}$ Department of Community Medicine and Family Medicine, All India Institute of Medical Sciences, Rajasthan, India

Received: 23 July 2016

Accepted: 16 August 2016

*Correspondence:

Dr. Navgeet Mathur,

E-mail: mathurdrnavgeet@gmail.com

Copyright: (c) the author(s), publisher and licensee Medip Academy. This is an open-access article distributed under the terms of the Creative Commons Attribution Non-Commercial License, which permits unrestricted non-commercial use, distribution, and reproduction in any medium, provided the original work is properly cited.

\section{ABSTRACT}

Background: Cervical cancer is one of the most common cancers of Indian females. Western Rajasthan differs a lot from rest of India in respect of geographical conditions, environment, culture, population density etc. and it also has relatively lower literacy rate which is one of the risk factor for many diseases. The objective of this study was to estimate the prevalence of cervical cytological pattern in females of western Rajasthan by using conventional Papanicolaou (Pap) smears for the screening of inflammatory, premalignant and malignant lesions of the cervix.

Methods: This cross sectional study was conducted at tertiary care institute of western Rajasthan for 1.5 year duration, on 1768 females who were screened by Pap smear examination. After staining with conventional Papanicolaou technique, all smears were classified as per Bethesda nomenclature.

Results: Out of 1768 smears 1039 (58.7\%) were abnormal Pap smears, 445 (25.1\%) were normal Pap smears while $284(16.1 \%)$ smears had inadequate sample material to be examined. Out of 1039 abnormal smears, $956(92.01 \%)$ smears reported to have inflammatory/reactive changes whereas $26(2.50 \%)$ had atrophic changes in Pap smear and abnormality in epithelial cell was reported in 57(5.49\%) smears.

Conclusions: Pap smear examination is an effective screening procedure to detect cervical cytological abnormalities. Routine cytological screening by Pap smear should be offered to all women above 19 years or within 3 years of sexual activity. It is recommended to improve the awareness about the disease amongst females and skills of health care personal about proper preparation of Pap smear.

Keywords: Cervical pattern, Bethesda system, Pap smear

\section{INTRODUCTION}

Cervical cancer is one of the leading cancers in women with an estimated 500,000 new cases every year, of which $80 \%$ occur in developing countries. ${ }^{1}$

In India it is estimated, that the number of cases are over $140,000 .^{1,2}$ Cervical cancer is the most common cancer among women in India and second most common cancer in the world as a whole. ${ }^{2-5}$ India has the largest burden of cervical cancer patients in the world and one of every five cervical cancer patients belongs to this country. ${ }^{6}$ There is an urgent need for initiation of community screening and educational programs for the control and prevention of cervical cancer in India. ${ }^{7}$ The Papanicolaou (Pap) test is a screening test performed using the cells from the uterine cervix. This test was introduced by George Papanicolaou as a cervical pathology screening test in $1941 .^{8}$

The role of the pap smear as a cancer screening tool for the cervix at an early stage has been substantiated by several studies in the last 50 years and it is widely used in 
developed countries by which there is a decrease in incidence and mortality of cervical cancer. ${ }^{9-13}$

Pap test can detect $75 \%$ endometrial cancers and $90 \%$ of cervical cancers. ${ }^{14}$ Unfortunately some developing countries lack this facility to carry out widespread Pap screening. ${ }^{15-17}$

Not much work regarding this has been done and documented in this part of the country, so this study was designed to assess the prevalence and pattern of cervical lesions using conventional Pap smear method.

The objective of this study was to detect prevalence and pattern of cervical cytological changes of study population by using conventional Papanicolaou (Pap) smear for the screening of inflammatory, premalignant and malignant lesions of the cervix.

\section{METHODS}

This study was conducted at a tertiary care institute of western Rajasthan over a period of 1 year 5 months (August 2013 to December 2014) and a total of 1768 patients were included, who reported to hospital with complaints of vaginal discharge and inter menstrual bleeding (age between 19 to 84 years) by complete enumeration. All the females with above mentioned complaints were included in the study and patients with any other major medical illness were excluded, along with those who denied to consent for the study. Cytological smear samples were collected by the Ayre's spatula after obtaining informed consent from the patients. Ayre's spetula was rotated five times in the clockwise direction, with the central longer bristles in the cervical canal. The material was quickly smeared on two glass slides and put in the Coplin jar containing 95\% ethyl alcohol. Then the smears were stained using the conventional Papanicolaou technique. All the smears were stained by qualified cytotechnologists and then examined under light microscopy. Slides were reported as normal smear, inflammatory smear and assigned a category according to the Bethesda system $2001 .^{18}$ All abnormal epithelial lesions (SIL) were categorized under: atypical squamous cell of undetermined significance (ASCUS), low-grade squamous intraepithelial lesion (LSIL), atypical squamous cell (ASCH) cannot exclude high grade squamous intraepithelial lesion (HSIL), highgrade squamous intraepithelial lesion (HSIL), atypical glandular cells of undetermined significance (AGUS) and other atypical cells not otherwise specified. The malignant categories were squamous cell carcinoma (SCC), adenocarcinoma and other malignancy not otherwise specified.

\section{RESULTS}

Total of 1768 Pap smears were examined in the laboratory. Out of 1768 Pap smears there were 1039 (58.77\%) abnormal Pap smears (including epithelial cell abnormalities, reparative/reactive cellular changes of inflammation, infections and atrophic smear) while 445 were normal smears $(25.17 \%)$ and 284 had unsatisfactory or inadequate samples $(16.06 \%)$. The inadequate or smears obscured with blood were allocated in the unsatisfactory group (Table 1).

Table 1: Cytological finding of pap smears examination.

\begin{tabular}{|ll|}
\hline Cytological findings & $\begin{array}{l}\text { Frequency (percentage } \\
\text { of total cases) }\end{array}$ \\
\hline Normal smear & $445(25.17)$ \\
\hline Abnormal smear (1039) & \\
\hline Epithelial lesions & $57(3.22)$ \\
\hline $\begin{array}{l}\text { No inter epithelial lesions } \\
\text { or malignancy }\end{array}$ & $982(55.54)$ \\
\hline Unsatisfactory smear (284) \\
\hline Inadequate sample & $114(6.45)$ \\
\hline Obscured with blood & $170(9.62)$ \\
\hline Total & $\mathbf{1 7 6 8}(\mathbf{1 0 0})$ \\
\hline
\end{tabular}

Table 2: Number and percentage of the specific finding in abnormal pap smears with respect to mean age.

\begin{tabular}{|lll|}
\hline Abnormal Pap smears & \multicolumn{1}{|c|}{$\begin{array}{l}\text { Frequency } \\
\text { (percentage of } \\
\text { total cases) }\end{array}$} & $\begin{array}{l}\text { Mean } \\
\text { age } \\
\text { (years) }\end{array}$ \\
\hline $\begin{array}{l}\text { Negative for intraepithelial lesion or malignancy } \\
\text { (982 cases) }\end{array}$ & 37.9 \\
\hline Inflammatory/reactive & $956(54.07)$ & 68 \\
\hline Atrophic & $26(1.47)$ & \\
\hline Epithelial lesion (57 cases) & $23(1.3)$ & 45 \\
\hline ASC-US & $5(0.28)$ & 54 \\
\hline ASC-H & $14(0.79)$ & 39.5 \\
\hline LSIL & $8(0.45)$ & 51.5 \\
\hline HSIL & $3(0.17)$ & 64.6 \\
\hline Squamous cell carcinoma & $4(0.23)$ & 41 \\
\hline Atypical glandular cells & $\mathbf{1 0 3 9}$ & \\
\hline Total abnormal smear & \\
\hline
\end{tabular}

Of the 1039 abnormal smears 57 smear were reported to have epithelial pathological changes. They represented $5.4 \%$ (57/1039) of abnormal Pap smears and 3.22\% $(57 / 1768)$ of total smears taken.

The examination of the 57 abnormal smears with their mean ages revealed that there were 23 smears of ASC-US (45 years), 5 smears of ASC-H (54 year), 14 smears of LSIL (39.5 years), 8 smears of HSIL (51.5 year), 4 smears of AGUS (41 years), and 3 smears of SCC (64.6 years) (Table 2).

Among patients with abnormal Pap findings cervical erosion, cervicitis, vaginitis and cervical hypertrophy were the most common pathological conditions observed. 
Table 3: Comparison of results with other studies

\begin{tabular}{|llllll|}
\hline Diagnosis & Current study $\%$ & Bal et al $\%^{24}$ & Shekhar H et al \% & Patel et al \% & Gupta S et al $^{23}$ \\
\hline Normal & 25.17 & 16.7 & 35.2 & 19.6 & $*$ \\
\hline Inflammatory & 54.07 & 74.3 & 52.3 & 57.8 & $*$ \\
\hline ASCUS & 1.3 & 0.3 & 1.9 & 4.12 & 3.36 \\
\hline ASCH & 0.28 & $*$ & 0.9 & $*$ & 0.22 \\
\hline LSIL & 0.79 & 2.7 & 1.4 & 0.1 & 1 \\
\hline HSIL & 0.45 & 0.7 & 1.8 & 0.1 & 0.34 \\
\hline SSC & 0.17 & 1.3 & 0.6 & 0.7 & 0.41 \\
\hline AGUS & 0.23 & $*$ & $*$ & 0.5 & 0.6 \\
\hline
\end{tabular}

*Data not available.

\section{DISCUSSION}

Cervical cancer is a potentially preventable cancer. It is preceded by premalignant lesions which may take 5-15 years to progress to invasive cancer. If detected and treated timely, pre-invasive disease has nearly 100 per cent cure rate with simple surgical procedure, while advanced cancers have less than 35 per cent survival rates. ${ }^{19}$ It has been estimated that in India, even with a major effort to expand cytology services, it will not be possible to screen even one-fourth of the population once in a lifetime. ${ }^{20}$ Among various risk factors in these women, age at marriage less than 18 years, high parity and illiteracy leading to poor genital hygiene was observed to be the prominent risk factors associated with morbidity. These risk factors have also been reported as significant association with cancer cervix in few other studies. $^{21-23}$

We examined 1768 Pap smears out of which only 1,484 smears $(83.8 \%)$ were found to be satisfactory and 284 smears $(16.1 \%)$ were unsatisfactory, similar findings were reported in the study by Gupta $\mathrm{S}$ et al. ${ }^{24}$ Proportion of inadequate smears ranged from $0.2-5 \%$ in other studies. ${ }^{25-28}$ Such high percentage of inadequate sample in current study warrants the need of training of healthcare personals about proper preparation of Pap smear in this region of India.

In the present study there were 1039 (58.78\% of total smears) abnormal Pap smears out of which 956 (92.01\%) were inflammatory smears including reparative or reactive cellular changes of inflammation, infections and atrophic smear. Cytological smear presented with inflammatory lesions were having only neutrophils and bacteria on the slide with no atypical cells or dysplasia, indicating the importance of proper hygiene maintenance in prevention of cervical epithelial lesions.

In this study smears with abnormal epithelial changes (57) represented 5.4\% (57/1039) of abnormal Pap smears and $3.22 \%(57 / 1768)$ of total smears taken. According to previous studies prevalence rates of abnormal epithelial changes ranges from $1.392-7.8 \%$ in India. ${ }^{29-32}$ Out of these 57 smears of abnormal epithelial changes there were 23 smears of ASCUS (40.35\%), 5 smears of ASC-H $(8.77 \%), 14$ smears of LSIL $(24.56 \%), 8$ smears of HSIL (14.04\%), 4 smears of AGUS (7.02\%) and 3 smears of $\operatorname{SSC}(5.26 \%)$.

In current study, mean age of patients with LSIL was 39.1 years, and those with ASC-H, HSIL and carcinoma were 54, 51.1 years and 64.6 years respectively. The incidence of HSIL and SCC was greatly increased in the above 50 years age group indicating the gradually increasing incidence of malignancy with age. ${ }^{28}$ These results are in accordance with the studies of Bal et al and Elhakeem et al. ${ }^{24,25}$ We also compared the results obtained in this study with few other studies. The results of previous studies showed relevance with overall epithelial abnormalities as found in current study in western Rajasthan (Table 3).

\section{CONCLUSION}

Pap test is a cost effective cancer screening test and is a simple method to detect various non-neoplastic as well as neoplastic lesions of cervix. Early detection of precancerous lesions by Pap smear and subsequent proper treatment can be helpful in prevention of cervical cancer. As we know that cervical cancer is the leading malignancy in Indian women so every woman by the age of 19 or within 3 years of sexual activity should undergo the Papanicolaou (Pap) test.

In an area like western Rajasthan where female health is still a neglected aspect, such simple technique is a boon to screen the fatal disease at an early stage and improve the prognosis of the disease. It has been concluded that there is need of training of healthcare personal about proper sampling and preparation of Pap smear in this part of the country. Poor hygiene, lack of knowledge and awareness, are also responsible factors for the abnormal Pap smears which need special attention after early detection in prevention of cancer activity. 
Funding: No funding sources

Conflict of interest: None declared

Ethical approval: The study was approved by the Institutional Ethics Committee

\section{REFERENCES}

1. Juneja A, Sehgal A, Sharma S, Pandey A. Cervical cancer screening in India: Strategies revisited. Indian J Med Sci. 2007;61:34-47.

2. NCMH background papers-burden of disease in India. New Delhi: Ministry of Health and Family Welfare, Government of India; 2005.

3. Desai M. An assessment of community based cancer screening program among Indian Women Using the Anganwadi Workers. Obstet Gynecol Ind. 2004:54:483-7.

4. Adhikary AK, Banik U, Numaga J, E Suzuki, T Inada, $\mathrm{N}$ Okabe, et al. Heterogeneity of the fiber sequence in subgenus $\mathrm{C}$ adenovirus. J Clin Pathol. 2004;57:612-7.

5. Toews HA. The abnormal pap smear: a rationale for follow up. Can Fam Physician. 1983;29:759-62.

6. Guidelines for cervical cancer screening programme. Government of India-World Health Organization Collaborative Programme, 2006.

7. Murthy NS, Chaudhary K, Saxena S. Trends in cervical cancer incidence: indian scenario. Eur J Cancer Prev. 2005;14:513-8.

8. Papanicolaou GN, Traut HF.The diagnostic value of vaginal smears in carcinoma of the uterus. Am J Obstet Gynecol. 1941;42:193-206.

9. Miller $\mathrm{AB}$, Chamberlain J, Day NE, Hakama M, Prorok PC. Report on a workshop of the UICC project on Evaluation of Screening for Cancer. Int J Cancer. 1990;46:761-9.

10. Walton RJ. The task force on cervical cancer screening programs. Can Med Assoc J. 1976;114:981.

11. Hakama M, Rasanen VU. Effect of a mass screening program on the risk of cervical cancer. Am J Epidemiol. 1976;103:512-7.

12. Laara E, Day NE, Hakama M. Trends in mortality from cervical cancer in the nordic countries: Association with organized screening programs. Lancet. 1987;1:1247-9.

13. Anderson GH, Boyes DA, Benedet JL, Le Riche JC, Matisic JP, Suen KC, et al. Organization and results of the cervical cytology screening program in British Columbia. 1955-85. Br Med J (Clin Res Ed). 1988 296:975

14. Padubidri V, Daftary SN. Gynecological diagnosis. In: Howkins and Bourne Shaw's textbook of Gynecology. 13th ed. Noida: Elsevier India Private Ltd; 2004:77.

15. Zamani N. Management of abnormal cervical cytology. J Coll Physc Surg Pak. 1994;4:28-9.

16. Yousaf A, Yousaf NW. Review of cervical intra epithelial neoplastic (CIN) latest concepts of screening and management protocol. Pak J Obstet Gynaecol. 1992;5:23-5.

17. Singh P, Ilancheran A. The pap or cervical smear and the role of colposcopy in screening for carcinoma of the cervix. Singapore Med J. 1989;30:302-5.

18. Solomon D, Davey D, Kurman R, Moriarty A, O'Connor D, Prey M. Forum group members; Bethesda 2001 Workshop. The 2001 bethesda system: terminology for reporting results of cervical cytology. JAMA. 2002;287:2114-9.

19. Dinshaw KA, Shastri SS. Screening for cervical cancer in India. Natl Med J India. 2001;14(1):1.

20. Juneja A, Sehgal A, Sharma S, Pandey A. Cervical cancer screening in India: Strategies revisited. Indian J Med Sci. 2007;61(1):34-47.

21. Dutta PK, Upadhyay A, Dutta M, Ganguly SS. A case control study of cancer cervix patients attending Command Hospital, Pune. Ind J Cancer. 1990;27:101-8.

22. Caplash N, SobtiC. Epidemiology of cervical cancera case control study on north indian population. Indian J Cancer. 1999;36:179-85.

23. Prabhakar AK, Menon JR. Age at marriage and cervical cancer incidence. Indian $\mathrm{J}$ Cancer 1995;2:63-8.

24. Bal MS, Goyal R, Suri AK, Mohi MK. Detection of abnormal cervical cytology in Papanicolaou smears. J Cytol. 2012;29:45-7.

25. Elhakeem HA, Al-Ghamdi AS, Al-Maghrabi JA. Cytopathological pattern of cervical Pap smear according to the Bethesda system in Southwestern Saudi Arabia. Saudi Med J. 2005;26:588-92.

26. Shekhar H, Pancharia A, Chauhan S, Kaur A, Chauhan S. Cytological pattern of cervical papanicolaou smear in rajasthan. Int J Dent Med Res. 2014:1-7.

27. Patel MM, Pandya AN, Modi J. Cervical Pap smear study and its utility in cancer screening, to specify the strategy for cervical cancer control. Natl J Com Med. 2011;1:49-51.

28. Gupta S, Sodhani P, Halder K, Chachra KL, Singh $\mathrm{V}$, Sehgal A. Age trends in pre-cancerous and cancerous lesions of the uterine cervix in a cytology screening programme: what should be the target age group for a major thrust of screening in resourcelimited settings? Cytopathology. 2008;19(2):106-10.

29. Misra JS, Singh U. Results of long term hospital based cytological screening in asymptomatic women. Diagn Cytopathol. 2006;34:184-7.

30. Patel TS, Bhullar C, Bansal R, Patel SM. Interpreting epithelial cell abnormalities detected during cervical smear screening: a cytohistologic approach. Eur J Gynaecol Oncol. 2004;25:725-8.

31. Misra JS, Srivastava S, Singh U, Srivastava AN. Risk-factors and strategies for control of carcinoma cervix in India: Hospital based cytological screening experience of 35 years. Indian $\mathrm{J}$ Cancer. 2009;46:155-9.

32. Mulay K, Swain M, Patra S, Gowrishankar S. A comparative study of cervical smears in an urban 
hospital in India and a population based screening program in Mauritius. Indian J Pathol Microbiol. 2009;52:34-7.

33. Gupta S, Sodhani P, Halder K, Chachra KL, Sardana $\mathrm{S}$, Singh V, et al. Spectrum of epithelial cell abnormalities of uterine cervix in a cervical cancer screening programme: implications for resource limited settings. Eur J Obstet Gynecol Reprod Biol. 2007;134:238-42.

Cite this article as: Rawat K, Rawat N, Mathur N, Mathur M, Chauhan N, Tinna R. A study of cytological pattern of cervical papanicolaou smears in western Rajasthan. Int J Reprod Contracept Obstet Gynecol 2016;5:3186-90. 